\title{
FACTORS INFLUENCING PRE-ECLAMPSIA/ECLAMPSIA OUTCOMES IN HIGH-RISK PATIENTS IN ZIMBABWE
}

\section{Mudokwenuy-Rawdon}

D Litt et Phil student, Department of Advanced Nursing Sciences, University of South Africa

Senior Lecturer, Faculty of Nursing, Zimbabwe University

\section{Bezuidenhout}

D Litt et Phil, Senior Lecturer, Department of Health Studies, University of South Africa

\author{
VJ Ehlers \\ D Litt et Phil \\ Senior Lecturer, Department of Health Studies, University of South Africa \\ Corresponding author: ehlersvj@unisa.ac.za
}

Keywords: case fatality rate; maternal mortality ratio; quality care; risk factor; severe pre-eclampsia/eclampsia

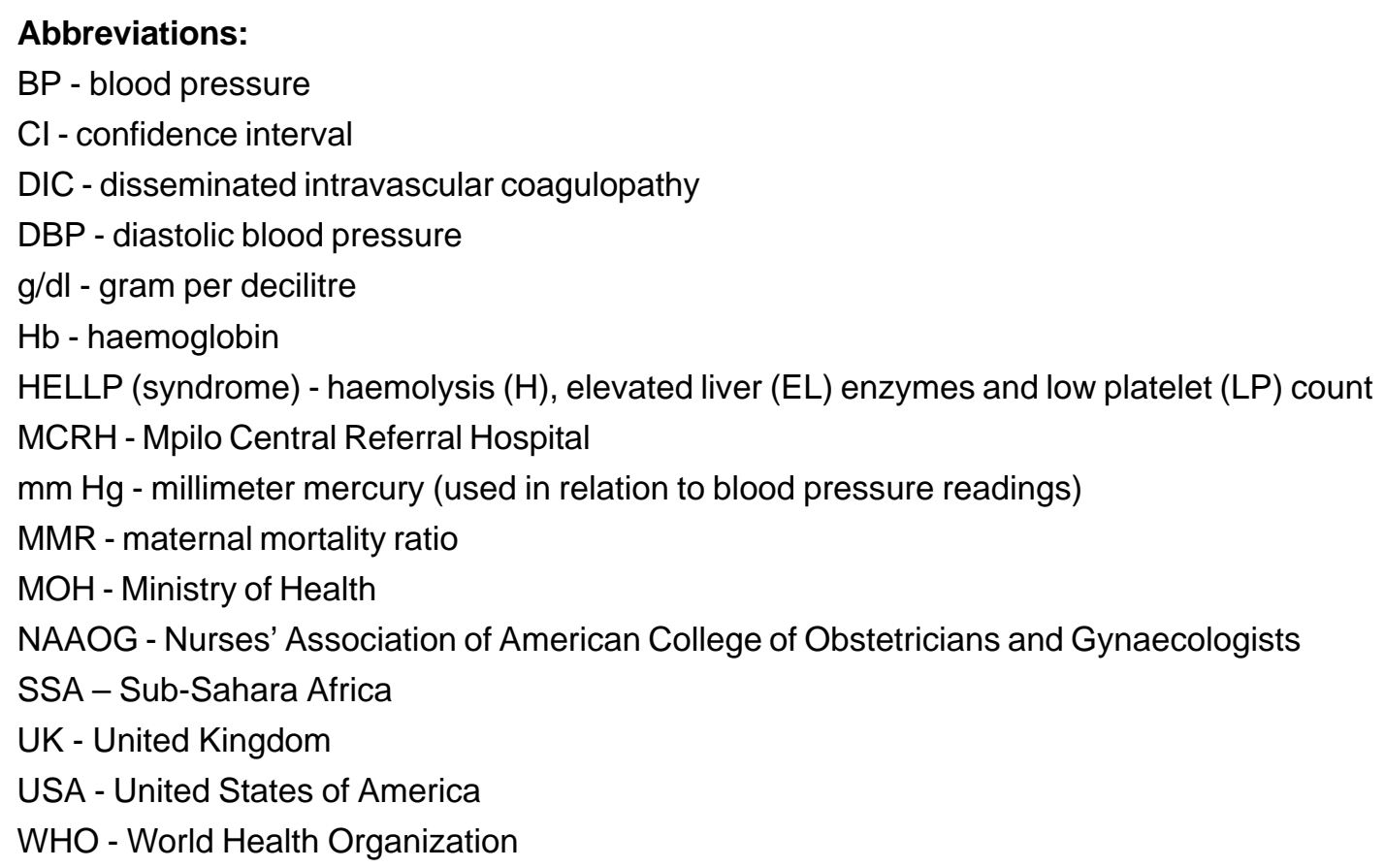

\section{SUMMARY}

Severe pre-eclampsia/eclampsia remains one of the major causes of maternal mortality in Zimbabwe. Based on this problem, factors associated with maternal mortality due to severe pre-eclampsia/eclampsia were investigated in an effort to improve pregnancy outcomes in Zimbabwe. Cases and controls were selected from 318 obstetric records of patients with severe pre-eclampsia/eclampsia to conduct a retrospective case-control study. (Cases referred to patients who were diagnosed with severe pre-eclampsia/eclampsia and who died from these conditions while controls survived these conditions). No significant factors could be identified which influenced maternal deaths among women suffering from severe pre-eclampsia/eclampsia. Magnesium sulphate was not routinely administered, as recommended internationally. Cases apparently received better reported care than controls. Recommendations based on this research report include improved midwifery education and in-service training, regular audits of patients' records and changed policies for managing these conditions more effectively in Zimbabwe. 


\section{OPSOMMING}

Ernstige pre-eklampsie/eklampsie bly een van die hoofoorsake van moederlike sterftes in Zimbabwe. Gebaseer op die probleem is faktore wat verband hou met moederlike sterftes as gevolg van ernstige pre-eklampsie/eklampsie ondersoek, in 'n poging om die swangerskapsuitkomstes in Zimbabwe te verbeter. Gevalle en kontroles is geselekteer uit 318 ernstige pre-eklampsie/eklampsie obstetriese rekords ten einde 'n retrospektiewe gevallekontrolestudie uit te voer. Geen beduidende faktore was identifiseerbaar wat moederlike sterftes onder vrouens met ernstige pre-eklampsie/eklampsie beïnvloed het nie. Magnesiumsulfaat was nie as roetine, teenstrydig met internasionale aanbevelings, toegedien nie. Volgens verslae het gevalle klaarblyklik beter sorg gekry as kontroles. (Gevalle is gedefinieer as pasiënte wat met pre-eklampsie/eklampsie gediagnoseer was en daaraan beswyk het terwyl kontroles die toestande oorleef het). Aanbevelings wat op die navorsingsverslag gegrond is, sluit in dat vroedvroue se onderrig en indiensopleiding verbeter moet word, pasiënte se rekords aan gereelde ouditering onderwerp moet word, en dat beleid verander moet word om die toestande in Zimbabwe meer effektief te beheer.

\section{INTRODUCTION}

"Pre-eclampsia is a multisystem disorder that is usually associated with raised blood pressure and proteinuria but, when severe, may cause pathology of the women's liver, kidneys, clotting system, and brain. The placenta is also involved with increased risk or poor growth and early delivery for the baby. It is a relatively common complication of pregnancy, and can occur at any time during the second half of pregnancy or the first few weeks after delivery... Eclampsia, defined as the occurrence of one or more convulsions (fits) in association with the syndrome of pre-eclampsia, is a rare but serious complication" (Duley, Gulmezoglu \& Henderson-Smart, 2000:1). Eclampsia is a condition peculiar to pregnant or newly delivered patients. It is characterised by convulsions, which occur as a result of raised blood pressure associated with pregnancy (WHO, 1996:14). At the hospital where this research was conducted no distinction was made between eclampsia and pre-eclampsia. Consequently this research used the term severe pre-eclampsia/ eclampsia as indicating the total range of women affected by this condition. The diagnoses in the patients' records were accepted as indicating whether or not any specific woman suffered from severe preeclampsia/eclampsia.

The high maternal mortality ratio (MMR), calculated as the number of maternal deaths divided by the number of live births (WHO, 1996:99) in developing countries, remains a major global concern. Every year 600000 women die from causes associated with pregnancy and childbirth (WHO, 1999:1). Almost 90.0 percent of these global maternal deaths occur in Sub-Sahara Africa (SSA) and Asia (Starrs, 1997:1). While women in Northern Europe have a 1:4 000 chance of dying from pregnancy related complications, those in Africa have a 1:16 chance (Starrs, 1997:1). This scenario depicts maternal mortality as a sensitive indicator of inequality in socio-economic status and the disparities between the developed countries and Africa. Bennett and Brown (1999:692) define maternal mortality as a death that occurs as a result of pregnancy or childbirth complications or as a consequence of pregnancy within 42 days after delivery or abortion.

A Zimbabwean study by Ashworth (1990:211) indicates that abortion, severe pre-eclampsia/eclampsia, obstetric (including ante-, intra- and post-partum) haemorrhage, obstructed labour and puerperal sepsis are the leading causes of maternal deaths. Post-abortion complications and severe pre-eclampsia/eclampsia account for the majority of the global obstetric deaths (WHO, 1999:13). Severe pre-eclampsia/eclampsia accounts for 10 to 15 percent of the total maternal deaths in developing countries (AbouZahr \& Royston, $1991: 8)$. According to Duley et al. (2000:2) pre-eclampsia/eclampsia complicates one in 100 deliveries in developing countries and accounts for approximately 10 percent of direct maternal deaths globally. In Zimbabwe, at Mpilo Central Referral Hospital (MCRH) in Bulawayo, out of 116 reported obstetric deaths, 24 (20.7 percent) of these deaths were due to severe preeclampsia/eclampsia (MCRH Obstetric Records 19941997). In the same period puerperal sepsis accounted 
for 12.9 percent, haemorrhage for 12.1 percent and other obstetric complications for 14.6 percent of obstetric deaths. Thus investigating factors contributing to maternal deaths among women suffering from severe pre-eclampsia/eclampsia would also address factors contributing to large numbers of maternal deaths, and ultimately help to reduce these numbers.

According to a United Kingdom (UK) report (Department of Health, 1994:iv) on confidential enquiries into maternal mortalities in the UK, women often died when the care they received was substandard. The fact that some high-risk women died and others survived was the reason why this study was conducted, in order to identify factors discriminating between non-surviving (cases) and surviving (controls) women hospitalised at MCRH with severe pre-eclampsia/eclampsia. The study intended to establish whether the quality of care those women received influenced their chances of surviving obstetric complications. The purpose of the study was to identify factors associated with maternal mortality among non-surviving (cases) and surviving (controls) women hospitalised for severe pre-eclampsia/ eclampsia at MCRH from 1 January 1995 until 31 December 1997.

The research questions, which guided this research, were:

- Is there a difference in selected physiological factors associated with maternal mortality due to severe pre-eclampsia/eclampsia between non-surviving (cases) and surviving (controls) women hospitalised at MCRH during 1995, 1996 and 1997?

- Is there a difference in selected aspects of the standard of maternity care received by nonsurviving (cases) and surviving (controls) women hospitalised for severe pre-eclampsia/ eclampsia at MCRH during 1995, 1996 and $1997 ?$

The following hypotheses were advanced for this study:

- There is a difference in selected physiological factors associated with maternal mortality due to severe pre-eclampsia/eclampsia between non-surviving (cases) and surviving (controls) women hospitalised at the MCRH during 1995 , 1996 and 1997.
- There is a difference in selected aspects of standard of maternity care received by nonsurviving (cases) and surviving (controls) women hospitalised for severe pre-eclampsia/ eclampsia at MCRH during 1995, 1996 and 1997.

\section{LITERATURE REVIEW}

Studies of maternal mortality show that every year over half a million women world-wide die in and around childbirth and that 99.0 percent of these deaths occur in the developing countries (AbouZahr \& Royston, 1991:1; WHO, 1995:1). For every woman who dies, a further 10 to 16 are handicapped or suffer from serious chronic illnesses subsequent to the delivery of their babies. Some women eventually die from these chronic conditions (Downe, 1991:33; Paul, 1993:745). It is estimated that 55 percent of the world's maternal deaths occur in Asia and Africa (WHO, 1995:2). About 150000 deaths occur annually in SSA, with extremely high ratios (over 1000 per 100000 live births) in the Eastern and Western regions of Africa (Howson, Harrison, Hotra \& Law, 1996:85; WHO, 1995:2).

The Nurses' Association of American College of Obstetricians and Gynaecologists (NAAOG) refers to quality as a "... state of agreed-upon excellence" (NAAOG, 1990:2). Definitions of quality emphasise characteristic features of excellence and clinical standards. Effectiveness reflects the degree of achieved desired effects such as a reduction in mortality and morbidity rates. On the other hand, efficacy as an outcome of care, refers to benefits received by individual consumers of health care (Abramson, 1990:49).

Two important factors for assessing the quality of care are standards and criteria and their vital role in clinical practice for achieving desired maternity care outcomes. As the NAAOG (1990:20) states "... standards are a consensus agreement regarding the level of excellence of care." They also possess a legal aspect, which imposes binding responsibilities for which care-providers have to be accountable (Lindberg, Hunter \& Kruszewski, 1994:53).

Bennett and Brown (1999:117) propose a clinical audit, which involves evaluating patients' records concur 
rently with treatment or retrospectively after discharge. The emphasis is on systematic evaluation of the care rendered to patients based on what is written in their records. The underlying assumption is that care recorded reflects care rendered, and care not recorded reflects care not rendered. This study relied on records for information about aspects of care, associated with maternal mortality or survival due to severe pre-eclampsia/eclampsia, by means of using a retrospective casecontrol design, in an effort to identify factors influencing the quality of nursing care rendered to these patients.

A retrospective obstetric audit can identify deficiencies in care delivery and in the documentation system. Lack of standardisation of what should be recorded in the obstetric records and poor documentation are some of the limiting factors in auditing care rendered to patients. The structure, process and outcome, as the three broad criteria proposed by Donabedian (1986:100), can be utilised to judge the quality of health care. As Abramson (1990:480) states, "... the quality of health care may be judged from information about effects (outcome evaluation), about the performance of activities (process evaluation), or about facilities and setting (structure evaluation)."

\section{Hypertensive disorders of pregnancy}

In medical terminology "blood pressure" describes the pressure of blood in the aorta and the large arteries that branch from it (Schauf, Moffett \& Moffett, 1990:338). Two measurements (systolic and diastolic pressures) indicate the two values of the blood pressure. The systolic pressure refers to the ejection phase of the cardiac cycle while the diastolic pressure is the minimum value of the ventricular diastole (Schauf et al. 1990:338).

Hypertensive disorders of pregnancy are characterised by abnormally high blood pressure. "Once blood pressure rises above a certain level, however, there is a risk of direct damage to the blood vessel wall, regardless of what caused the rise. This level is usually taken to be at least $170 \mathrm{~mm} \mathrm{Hg}$ systolic blood pressure or $110 \mathrm{~mm} \mathrm{Hg}$ diastolic. Risks of the mother related to such high blood pressures include kidney failure, liver failure and cerebrovascular haemorrhage (stroke). For the baby, risks include fetal distress due to vasoconstriciton reducing the blood supply across the placenta, and placental abruption..." (Duley \& Henderson-Smart, 2000a:2).

According to Wallenburg (1989:382) raised blood pressure may appear for the first time during pregnancy or pre-exist before pregnancy, and in both instances, the woman may develop superimposed severe pre-eclampsia/eclampsia. Severe pre-eclampsia/eclampsia accounts for 10 to 15 percent of the total maternal deaths in developing countries (AbouZahr \& Royston, 1991:8), as documented by a number of studies covering a time span of twenty years. A study of 58 maternal deaths in rural Bangladesh, conducted from 1982 to 1983, showed that 20.0 percent of all the deaths were eclampsia-related (Khan, Jahan \& Begum, 1986:11). In South Africa, hypertensive disorders accounted for 30 percent of 660 maternal deaths, which occurred between January 1980 and December 1982 (Boes, 1987:161). Similarly, in Zimbabwe, Ashworth (1990:211) reported hypertensive disorders of pregnancy to be one of the major causes of maternal deaths.

According to Surratt (1993:501), uncontrolled severe pre-eclampsia/eclampsia often results in a multisystem vasospasm and endothelial damage. This results in widespread ischaemic lesions in the vital organs with resultant death. The major final cause of death due to hypertension in pregnancy (in South Africa) was reportedly intracranial haemorrhage, followed by rupture of the liver and post-partum haemorrhage (Moodley, 1998:29). The multisystem condition referred to as the HELLP syndrome is characterised by haemolysis $(H)$, elevated liver (EL) enzymes and low platelet (LP) count (Poole, 1995:557; Sibai, Ramadan, Usta, Salam, Mercer \& Friedman, 1993:1000). What has been found to be challenging about the HELLP syndrome is that it exhibits features resembling those of disseminated intravascular coagulopathy (DIC). The differential diagnosis requires an evaluation of the woman's coagulation factors (prothrombin time, partial thromboplastin time, and bleeding time). Whilst in women with the HELLP syndrome these factors are normal, the reverse is true in women with DIC. Cavanagh, Woods and O'Connor (1978:14) describe DIC as “.... state of hypercoagulability which eventually consumes platelets, fibrinogen, and factors V, VII and XII, sometimes to the point of total depletion." The difficulties created for care-providers by the two phenomena are that of mak 
ing a differential diagnosis. It is only those care-providers with a sound knowledge base and relevant experience who might be able to reach a correct differential diagnosis, if they have the necessary laboratory facilities to conduct the required analyses rapidly. However, despite the differences in their pathophysiology, both conditions cause serious threats to women's lives and only timely appropriate obstetric interventions may reduce the risk of maternal deaths associated with both these conditions.

\section{Treatment for hypertensive disorders of pregnancy}

Treatment for women with severe pre-eclampsia/eclampsia complicated by the HELLP syndrome and/or DIC require frequent assessment and careful monitoring of each intervention. This means that nurses and midwives play a vital role in detecting any signs of deterioration and in obtaining the required medical assistance. Drug treatments are influenced by the pathophysiology of each condition. For women with severe pre-eclampsia/eclampsia complicated with HELLP syndrome, immediate delivery is recommended (Lloyd \& Lewis, 1999:322). Coupled with this intervention is the use of anti-convulsant drug therapy, of which magnesium sulphate is the drug of choice in many countries following the WHO collaborative eclampsia trial of 1680 women in 1991 (WHO, 1995:20). This trial involved centres in Argentina, Brazil, Colombia, Ghana, India, Uganda, Venezuela, Zimbabwe and the Republic of South Africa (RSA). In the study, the effects of magnesium sulphate and diazepam were compared in 905 women in 23 centres. Magnesium sulphate and phenytoin were compared in over 775 women treated at four other centres. The findings showed that magnesium sulphate was more effective in reducing and preventing eclamptic convulsions than either diazepam or phenytoin - demonstrating magnesium sulphate's superiority as treatment of choice (WHO, 1995:13). Magnesium sulphate is reportedly the drug of choice in the United States of America (USA) and an estimated 60 percent of clinicians used magnesium sulphate in the UK (Duley \& Henderson-Smart, 2000a:1-2). Magnesium sulphate can be administered both intravenously and intramuscularly and could thus be administered by nurses even in outlying clinics. "Magnesium sulphate is cheap and relatively easy to produce, and so making it readily available for the care of women with eclampsia in both developed and developing countries should be a high priority" (Duley \& Henderson-Smart, 2000b:4).

However, nurses and midwives must be alert because magnesium sulphate can cause toxicity (Lloyd \& Lewis, 1999:324). Magnesium sulphate is known to induce loss of patellar reflexes, while lethargy and respiratory depression are observed above eight (8) $\mathrm{mEq} / \mathrm{L}$, and cardiac arrest may appear at levels above $12 \mathrm{~m} / \mathrm{Eq} / \mathrm{L}$ (Kaplan \& Repke, 1994:574).

For women with DIC, treatment essentially focuses on correcting clotting factors by giving frozen plasma, fresh blood or platelet concentrates (Craft, 1999:267). Women suspected to be suffering from both HELLP syndrome and DIC might benefit from combined treatments, in addition to supportive therapy in terms of assessment and surveillance.

Quality obstetric care can reduce the pathophysiological impact on all the systems including those caused by DIC. The development of DIC sets up a cascade, which significantly contributes to maternal death due to obstetric (including ante-, intra- and post-partum) haemorrhage. Royston and Armstrong (1989:85) state that a woman with antepartum haemorrhage roughly lives for about 12 hours while one with postpartum haemorrhage has only two hours to live without appropriate interventions. Thus early intervention is even more vital for maternal survival in cases of post-partum haemorrhage than in cases of ante-partum haemorrhage, emphasising the risk DIC poses to any pregnant woman's life.

To be effective in reducing maternal mortality levels, risk factors associated with women dying from pregnancy related complications, such as severe pre-eclampsia/eclampsia must be examined.

\section{RESEARCH METHODOLOGY}

\section{Research Design}

A retrospective unmatched case-control design was used to compare two groups (cases who died and controls who survived) of women admitted at the MCRH from 1 January 1995 to 31 December 1997, with severe pre-eclampsia/eclampsia. The population comprised 
173 admissions for severe pre-eclampsia/eclampsia. There were 24 recorded maternal deaths associated with severe pre-eclampsia/eclampsia.

\section{Sample size and sampling technique}

The sample was drawn from hospital obstetric records of women who were admitted with severe pre-eclampsia/eclampsia. Twenty-four severe pre-eclampsia/eclampsia maternal deaths were identified, making it the second most important cause (superceded only by post-abortion complications) of maternal deaths during the research period at $\mathrm{MCRH}$. From this population of 24 maternal deaths due to severe pre-eclampsia/eclampsia, 21 (87.5 percent) patients' records could be retrieved from MCRH's filing system. For each case (a woman who died from severe pre-eclampsia/eclampsia), records of two controls (women who survived this condition) were retrieved, as discussed under the data collection.

\section{Research setting}

The study site was MCRH in Bulawayo, which is the second largest city in Zimbabwe, lying in the western part of the country. The hospital is one of the two large central referral centres for high-risk patients in Zimbabwe (MOH, Zimbabwe, 1981:45). The hospital has a bed capacity of 1038 of which 233 beds are reserved for maternity patients. The 233 maternity beds, included 27 beds in the antenatal ward, 16 in the labour ward, 128 in the postnatal ward and 62 neonatal cots.

Two operating theatres with five recovery/high dependency beds (three adult beds and two incubators) form additional physical structures attached to the maternity unit. In 1995 and 1996, the bed occupancy rates were 99.9 and 84.5 percent respectively (MCRH Annual Report, Zimbabwe, 1996:9). The average length of stay was 3.9 days. The maternity unit's labour ward, delivers, on average, 12000 babies annually, or about 1000 babies per month, or more than 30 babies daily (MCRH Health Information Unit, 1995-1997).

The census conducted to provide background information to this study, revealed that there were, over the three-year period, 135 maternal deaths recorded of which 116 (85.9 percent) were maternal deaths due to obstetric complications. The majority of the obstetric deaths were due to abortion (39.6 percent) and severe pre-eclampsia/eclampsia (20.7 percent). Other causes accounting for the remaining 19 (14.1 percent) deaths included anaemia (one), anoxia (one), ectopic pregnancy (six), HIV/AIDS (seven), malaria (three) and molar pregnancy (one). The MMRs, calculated per 100 000 live births, were reportedly 407 for $1995,481.9$ for 1996 and 275.5 for 1997 , according to the records at $\mathrm{MCRH}$. (The reason for the apparent decline in MMRs reported for 1997 could not be explained from the data available from the patients' records. However, in spite of the apparent decline in 1997, pregnancy outcomes remained unfavourable for women admitted to $\mathrm{MCRH}$ ).

\section{Research instruments}

The hospital obstetrics census form and an obstetric record audit form were used to collect data. The hospital obstetrics census form collected data about the background information required to contextualise the research results of the study. The obstetric record audit form was used to obtain data required from the preeclampsia/eclampsia cases and controls. An experienced masters prepared midwifery lecturer, two statisticians from the University of Zimbabwe, and two nurse researchers from the University of South Africa, assessed the face validity of the items included in the obstetric record audit form. Modifications were made following the recommendations based on the first review. The format was then re-submitted to these experts for further reviews until there was more than 80 percent agreement on the relevancy of the items contained in the audit form (Talbot, 1995:282). The instrument was pre-tested with the obstetric records of five cases and ten controls admitted with severe pre-eclampsia/eclampsia at MCRH during 1994. (These records were excluded from the survey which covered the period 1 January 1995 to 31 December 1997). Pretesting of the checklists indicated that more specific categories should be created and that spaces should be provided for writing down additional information. This was done prior to embarking on the actual data collection phase.

The census data included information on annual admissions, deliveries, live births and maternal deaths obtained from the 1995, 1996 and $1997 \mathrm{MCRH}$ registers. The obstetric records audit form captured data from the severe pre-eclampsia/eclampsia cases and 
controls focusing on socio-demographic factors (residence, age, marital status, educational level and occupation), physiological factors ( $\mathrm{Hb}$ level, BP level and temperature level) and obstetric/gynaecological factors (gravidity, gestational age and type of severe pre-eclampsia/eclampsia). Severe pre-eclampsia/eclampsia criteria for measurement of the standard of care included antenatal care booking status (booked or unbooked), emergency care (summoning medical assistance, quarter to half hourly observations of BP, temperature, respiration and pulse), fluid intake and output recording, anti-hypertensive and/or anti-convulsant drug treatment, follow-up care (hourly to four hourly observations of $\mathrm{BP}$, temperature, respiration and pulse), type of delivery (vaginal delivery or caesarean section), evidence of medical reviews and documentation or omission of documentation of care provided. The standard care for severe pre-eclampsia/eclampsia was adopted and adapted from the WHO Safe Motherhood Midwifery Education Eclampsia Module 96.5 (WHO, 1996) for the management of patients presenting with severe pre-eclampsia/eclampsia.

\section{Ethical issues}

Approval for the research was requested from and granted by the Medical Research Council of Zimbabwe and the MCRH authorities. In this retrospective review of records, informed consent was not obtained from either the survivors (controls), or from the non-survivors' (cases') relatives. The study inflicted no harm on the subjects nor on their relatives as no names were disclosed at any stage to ensure confidentiality and anonymity. A coding system was used to ensure anonymity of patients and the data collected were used strictly for the purpose it was collected for. No specific person was mentioned in the discussion of the findings.

\section{Data collection procedure}

Data collection was carried out in phases addressing structure and process evaluation by means of the instruments developed to obtain the intended data. Information about the obstetric census variables was retrieved from the maternity unit's register for the period 1995, 1996 and 1997. The cases' and the controls' hospital numbers were identified from the admission and death registers. This information enabled the retrieval of the cases' and controls' obstetric records from the hospital medical records office. These records were subjected to thorough scrutiny in a separate office not accessible to anyone except the investigator and research assistant. Each case was given a code number, which it shared with its selected two controls to avoid using the same controls more than once (for example case $=1$, controls $=1 \mathrm{a}$ and $1 \mathrm{~b}$ ). These codes served to ensure anonymity throughout the research process. The lack of access to specific patients' files made matching each case with two controls for age, parity, diagnosis and haemoglobin status impossible. After consultation with statisticians it was decided to compare the data from two groups (cases versus controls) rather than the initially planned comparison of each case with two specific controls. Thus the data obtained from all cases constituted one category of data to be compared to the data obtained from all controls. Attempts to randomly select controls had to be abandoned due to a large number of missing files which could not be traced. The only possibility which remained was to continue requesting the files of all possible controls until 42 such files were obtained, amounting to convenience sampling of the controls. Thus the number of cases amounted to $21(n=21)$ and the controls to $42(n=42)$.

\section{Data analysis}

The data was organised for analysis under severe preeclampsia/eclampsia cases and controls. Odds Ratio (OR) and 95 percent confidence interval $(95 \% \mathrm{Cl})$ were estimated according to the Mantel-Haenszel ChiSquare Test or Fischer's Exact Test (Kahn \& Sempos, 1989:155). A separate analysis was performed using stepwise logistic regression to take into account the effect of potentially confounding variable of residence, age, marital status and occupation status. The OR was used to measure the impact of a possible risk factor. Possible categories for OR were greater than one or less than one (Kahn \& Sempos, 1989:56). When the value of $O R$ was greater than one, there was a significant increased risk between maternal mortality due to severe pre-eclampsia/eclampsia and the factor. On the other hand, when the OR was less than one the risk was reduced. This implied that there was no association between maternal death due to severe preeclampsia/eclampsia and the measured particular factor in cases where the OR was less than one (Kahn \& Sempos, 1989:56). 
Univariate descriptive statistics, defined by Polit and Hungler (1995:657) as statistical procedures for analysing a single variable for purposes of description, were used to analyse data from socio-demographic, physiological, obstetrical/gynaecological and health service factors (Jacobsen, 1997:30). Single table analyses utilised a combination of $95 \% \mathrm{Cl}$ for OR. The 95\% $\mathrm{Cl}$ and OR were calculated according to the Mantel-Haenszel Chi-Square Test or Fischer's Exact Test to determine significant variables and their association with risk of maternal deaths due to severe pre-eclampsia/eclampsia. Two-tailed tests for normal distribution for differences between proportions of cases and controls were used to allow comparative analysis to be reviewed, analysed and compared (Polit \& Hungler, 1995:408). Stepwise logistic regression tests were used to identify any further significance of variables and to determine whether the association of factors with maternal deaths still held after controlling for confounding variables such as urban and rural residence, age, marital status, education, occupational status and gravidity (Munro, 1997:292).

\section{RESEARCH RESULTS}

The total sample comprised 21 pre-eclampsia/eclampsia cases and 42 controls, amounting to a total of 63 records which were analysed.

\section{Socio-demographic factors}

Variables categorised under socio-demographic factors included urban-rural residence, age, marital status, educational and employment status.

\section{Urban-rural residence}

In both cases and controls, the majority (95.2 and 90.5 percent respectively) were urban residents. The number of cases (95.2 percent) who were from the urban setting was almost similar in distribution to that of the controls (90.5 percent). The maternal mortality risk was not significantly increased by place of residence ( $p$-value $=0.455, \mathrm{OR}=2.11,95 \% \mathrm{Cl}=0.19-3.85)$.

\section{Age}

The ages of both groups combined ranged from 15 to 49 years. The mean age was 24.9 for the cases and 25.7 for controls. Of the cases, 61.9 percent were between 20 and 29 years of age, while 38.1 percent of the controls were within the same age group. Only one (4.8 percent) case and four (7.1 percent) controls fell within the 40 to 49 year age group. The results showed no statistically significant difference between women whose age was below or above 25 years ( $p$-value $=$ $0.858, \mathrm{OR}=1.10,95 \% \mathrm{Cl}=0.33-3.66)$. The results suggested that women of all ages had the same chance of dying if they suffered from severe pre-eclampsia/ eclampsia during pregnancy.

\section{Marital status}

The women who were married were equally distributed among cases (76.2) and controls (76.2 percent). Marital status did not contribute to the risk of maternal mortality due to severe pre-eclampsia/eclampsia ( $p$-value $=$ $0.715, \mathrm{OR}=1.00,95 \% \mathrm{Cl}=0.23-2.79$ ).

\section{Educational status}

When the educational background of the cases and controls was compared, there was a slightly higher proportion (62.0 percent) of cases who received more than seven years of formal education than controls (52.4 percent). There were four patients in each group (cases and controls) whose education levels were not indicated on their records. The level of education was not significantly associated with the risk of maternal mortality due to severe pre-eclampsia/eclampsia in this sample ( $p$-value $=0.189, \mathrm{OR}=2.36,95 \% \mathrm{Cl}=0.37$ 11.66). However, more cases (72.2 percent) compared to controls (57.9 percent) attained more than seven years' schooling indicating a higher literacy level among those women who died compared to those who survived.

\section{Employment status}

With respect to formal employment, 100.0 percent of the cases and 90.5 percent of the controls were not in formal employment suggesting that these women were possibly depending on their husbands or other family members for financial support.

\section{Physiological factors}

Table 1 demonstrates the variables ( $\mathrm{Hb}$ level, DBP, mean DBP, gestational age) of the physiological factors that were considered for analysis with the MantelHaenszel Chi-Square Test or the Fisher's Exact Test. $\mathrm{Hb}$ level $\leq 11.00 \mathrm{~g} / \mathrm{dl}$, DBP $>110 \mathrm{mmHg}$ and mean DBP $>120 \mathrm{mmHg}$ were the exposure variables 
Table 1: Distribution of selected physiological factors of cases and controls by haemoglobin and diastolic blood pressure and risk of maternal death due to severe pre-eclampsia/eclampsia: Mpilo Central Referral Hospital 1995-1997. OR and 95\% $\mathrm{Cl}(\mathrm{n}=63)$

\begin{tabular}{|c|c|c|c|c|c|c|c|}
\hline \multirow{3}{*}{$\begin{array}{l}\text { Physiological } \\
\text { factors }\end{array}$} & \multicolumn{2}{|l|}{ Cases } & \multicolumn{2}{|l|}{ Controls } & \multicolumn{3}{|c|}{ Descriptive Statistics } \\
\hline & \multicolumn{2}{|l|}{$\mathrm{n}=\mathbf{2 1}$} & \multicolumn{2}{|l|}{$n=42$} & \multirow[b]{2}{*}{ OR } & \multirow[b]{2}{*}{$95 \% \mathrm{Cl}$} & \multirow[b]{2}{*}{ P-value } \\
\hline & Number & Percent & Number & Percent & & & \\
\hline \multicolumn{8}{|c|}{$\mathrm{Hb}$ level (normal=11 g/dl) } \\
\hline$\leq 11$ & 14 & $(66.7)$ & 21 & $(50.0)$ & 2.00 & $0.60-7.05$ & 0.213 \\
\hline$>11$ & 7 & (33.3) & 21 & $(50.0)$ & & & \\
\hline \multicolumn{8}{|c|}{ Highest DBP in mm Hg } \\
\hline$\geq 110$ & 17 & $(81.0)$ & 41 & $(97.6)$ & 0.10 & $0.00-1.19$ & $0.039^{\star} \mathrm{F}^{\star}$ \\
\hline$<110$ & 4 & $(19.0)$ & 1 & (2.4) & & & \\
\hline \multicolumn{8}{|c|}{ Mean DBP in $\mathrm{mm} \mathrm{Hg}$} \\
\hline$\geq 120$ & 5 & $(23.6)$ & 23 & $(54.8)$ & 0.26 & $0.06-0.93$ & $0.021^{*}$ \\
\hline$<120$ & 16 & $(76.2)$ & 19 & $(45.2)$ & & & \\
\hline
\end{tabular}

*Statistically significant $p$-values

${ }^{*}$ F=Fischer's exact test

considered under physiological factors for this study.

\section{Haemoglobin level}

Fourteen (66.7 percent) of the 21 cases had a haemoglobin level of $\leq 11 \mathrm{~g} / \mathrm{dl}$ compared to 21 (50.0 percent) of the 42 controls indicating the prevalence of anaemia in both groups. The mean $\mathrm{Hb}$ level was 9.3 $\mathrm{g} / \mathrm{dl}$ for the cases and $12.8 \mathrm{~g} / \mathrm{dl}$ for the controls, with ranges from 3 to 14 for cases and 6 to 14 for controls. Thus, the cases apparently had a lower $\mathrm{Hb}$ than the controls. When the risk of maternal mortality was analysed according to $\mathrm{Hb}$ level, women who were anaemic $(\mathrm{Hb}=s 11 \mathrm{~g} / \mathrm{dl})$ had the same chance of survival as those whose haemoglobin level was normal $(\mathrm{Hb}=>11)$ if they developed severe pre-eclampsia/ eclampsia $(p$-value $=0.213, \mathrm{OR}=2.00,95 \% \mathrm{Cl}=0.60$ 7.05). There were more cases (66.7 percent) than controls (50.0 percent) who were anaemic.

\section{Blood pressure level}

The DBP ranged from 82 to $150 \mathrm{~mm} \mathrm{Hg}$ in the cases and from 100 to $170 \mathrm{~mm} \mathrm{Hg}$ in the controls. The mean for the cases was $119.6 \mathrm{~mm} \mathrm{Hg}$ and for the controls it was $126 \mathrm{~mm} \mathrm{Hg}$. However, the median was $120 \mathrm{~mm}$ $\mathrm{Hg}$ in both groups with modes of $110 \mathrm{~mm} \mathrm{Hg}$ for the cases and $120 \mathrm{~mm} \mathrm{Hg}$ for controls as shown in Table 4.10. These DBP values unexpectedly indicated that the controls had slightly higher DBPs than the cases, which could not be accounted for from the patients' record sheets. This study considered any woman who had a DBP $\geq 110 \mathrm{~mm} \mathrm{Hg}$ to have developed severe pre-eclampsia/eclampsia. The results of the analysis showed that there was a significant association between maternal death and the DBP $\geq 110 \mathrm{~mm} \mathrm{Hg}$ ( $p$-value = $0.039, \mathrm{OR}=0.10,95 \% \mathrm{Cl}=0.00-1.19)$. However, a $95 \% \mathrm{Cl}$ 0.00-1.19 (including 1) suggests a weak risk of maternal mortality. This implies that further research 
in this area is required. A review of women's obstetric records showed that more controls (97.6 percent) than cases (81.0 percent) had DBP $\geq 110 \mathrm{~mm} \mathrm{Hg}$. In terms of a mean DBP of $120 \mathrm{~mm} \mathrm{Hg}$, the results demonstrated that women with a mean DBP >120 mm $\mathrm{Hg}$ were less likely to die from severe pre-eclampsia/ eclampsia than those whose mean DBP was $<120 \mathrm{~mm}$ $\mathrm{Hg}$ ( $p$-value $=0.021, \mathrm{OR}=0.26,95 \% \mathrm{Cl}=0.06-0.93)$. Extrapolating meaning from these two results the OR $=0.10$ for women with a mean DBP $>110 \mathrm{~mm} \mathrm{Hg}$ compared with the $\mathrm{OR}=0.26$ for women with a mean DBP $<120 \mathrm{~mm} \mathrm{Hg}$, indicates that women's risk of dying from severe pre-eclampsia/eclampsia more than doubled when their DBP rose from 110 to $120 \mathrm{~mm} \mathrm{Hg}$. The implication of this finding is that health care workers must do everything in their power to keep these women's diastolic blood pressures below $120 \mathrm{~mm} \mathrm{Hg}$ in order to enhance their chances of survival.

\section{Obstetric factors}

The two most important factors investigated under this heading were gravidity and gestational period.

\section{Gravidity}

Gravidity for both the cases and the controls showed that the most affected group was primigravidae (42.9 percent of cases, 54.8 percent of controls) and gravid $z$ four (43.3 percent of cases, 31.0 percent of controls) comprised the second largest group. The mean gravid for cases was 2.6, compared to the controls' mean of 2.5. There was no statistically significant difference in maternal mortality between women who were below or above gravida three $(p$-value $=0.847, O R=0.89,95 \%$ $\mathrm{Cl}=0.23-3.18)$.

\section{Gestational period}

The gestational period was considered in relation as to whether pregnancy was at term (40 weeks' gestation) or below term (preterm) up to 39 weeks' gestation. In cases, severe pre-eclampsia/eclampsia occurred more frequently at term than before term (57.1 percent) while 50.0 percent of the controls developed this condition at term and $50.0 \%$ percent before term. Out of the 21 cases, three (14.3 percent) developed the HELLP syndrome comprising of haemolysis $(H)$; elevated liver enzymes (EL) and low platelet count (LP), indicating a further progression of the disease requiring treatments different from those advised for severe pre-eclampsia/ eclampsia.

No statistical significant association was found between maternal mortality and gestational age of women with severe pre-eclampsia/eclampsia ( $p$-value $=0.427$, OR $=1.55,95 \% \mathrm{Cl}=0.47-5.28)$. However, there were more cases (61.9 percent) than controls ( 51.2 percent) who delivered at term. It could not be ascertained from the data available from patients' files whether or not women had a better chance of survival if the baby was delivered preterm but this possibility could not be refuted either.

\section{Standard of maternity care rendered to patients with severe pre-eclampsia/ec- lampsia at MCRH}

The standard of maternity care was evaluated by examining implemented interventions that were recorded as care received by the women suffering from severe pre-eclampsia/eclampsia at MCRH. Various descriptive words were used to record the presence or absence of specific interventions, including "given or not given," "administered or not administered," "done or not done," "recorded or not recorded," "complete or incomplete." The positive terms represented caring interventions implemented while the negative descriptive words depicted omissions of caring interventions. Some of the items were categorised under specific terms for rating and summation for analysis. The variables selected for analysis were as follows: antenatal care (booked or unbooked), emergency care (including summoning medical assistance, quarter to half hourly monitoring of $\mathrm{BP}$, temperature, respiration, pulse, anti-hypertensive/anti-convulsant drug treatment, fluid intake and output recording, follow-up care, hourly to four hourly monitoring of $\mathrm{BP}$, temperature, respiration and pulse, type of delivery and documentation of care provided). As all the women (all cases and all controls) were assessed daily by doctors, this aspect was excluded from the analysis as no differences would be detected.

\section{Antenatal care}

Out of 21 cases, 61.9 percent were booked for antenatal care compared to 50.0 percent of the 42 controls. When the antenatal care booking status of women was analysed, there was no significant association with increased maternal mortality risk ( $\mathrm{p}$ value $=0.375, \mathrm{OR}=0.62,95 \% \mathrm{Cl}=0.18-2.02$ ) 
Table 2: Distribution of cases and controls by standard of maternity care (as measured by selected implemented interventions) for severe pre-eclampsia/eclampsia care: Mpilo Central Referral Hospital 19951997. OR and $95 \% \mathrm{Cl}(\mathrm{n}=63)$

\begin{tabular}{|c|c|c|c|c|c|c|c|}
\hline \multirow{2}{*}{$\begin{array}{l}\text { Standard of } \\
\text { maternity care }\end{array}$} & \multirow{2}{*}{$\begin{array}{l}\text { Cases } \\
(n=21) \\
\text { Number }\end{array}$} & \multirow[b]{2}{*}{ Percent } & \multicolumn{2}{|l|}{$\begin{array}{l}\text { Controls } \\
(n=42)\end{array}$} & \multirow[b]{2}{*}{ OR } & \multirow[b]{2}{*}{$95 \% \mathrm{Cl}$} & \multirow[b]{2}{*}{ P-value } \\
\hline & & & Number & Percent & & & \\
\hline \multicolumn{8}{|c|}{ Antenatal care booking status } \\
\hline Unbooked & 8 & $(38.1)$ & 21 & $(50.0)$ & \multirow{3}{*}{0.62} & \multirow{3}{*}{$0.18-2.02$} & \multirow{3}{*}{0.375} \\
\hline & & & & & & & \\
\hline Booked & 13 & $(61.9)$ & 21 & $(50.0)$ & & & \\
\hline \multicolumn{8}{|l|}{ Emergency care } \\
\hline Not given & 4 & $(19.0)$ & 19 & $(45.2)$ & \multirow{3}{*}{0.28} & \multirow{3}{*}{$0.96-1.10$} & \multirow{3}{*}{$0.043^{*}$} \\
\hline & & & & & & & \\
\hline Given & 17 & $(91.0)$ & 23 & $(54.8)$ & & & \\
\hline \multicolumn{8}{|c|}{ Anti-hypertensive/anti-convulsant drug treatment } \\
\hline Not given & 2 & $(9.5)$ & 2 & $(4.8)$ & & & \\
\hline & & & & & 2.11 & $0.14-0.72$ & $0.407 \mathrm{~F}^{*}$ \\
\hline Given & 19 & $(90.5)$ & 40 & $(95.2)$ & & & \\
\hline \multicolumn{8}{|c|}{ Fluid intake and output recording } \\
\hline Not recorded & 3 & $(14.3)$ & 26 & $(61.9)$ & \multirow{3}{*}{0.10} & \multirow{3}{*}{$0.02-45$} & \multirow{3}{*}{$0.0004^{*}$} \\
\hline & & & & & & & \\
\hline Recorded & 18 & $(85.7)$ & 16 & $(38.1)$ & & & \\
\hline \multicolumn{8}{|l|}{ Follow-up care } \\
\hline Not given & 6 & $(28.6)$ & 30 & $(71.4)$ & \multirow{3}{*}{0.16} & \multirow{3}{*}{$0.04-0.16$} & \multirow{3}{*}{$0.001^{*}$} \\
\hline & & & & & & & \\
\hline Given & 15 & $(71.4)$ & 12 & $(28.6)$ & & & \\
\hline \multicolumn{8}{|l|}{ Type of delivery } \\
\hline $\begin{array}{l}\text { Caesarean } \\
\text { section }\end{array}$ & 19 & $(90.5)$ & 39 & $(92.9)$ & \multirow[t]{2}{*}{0.73} & \multirow[t]{2}{*}{$0.08-9.49$} & \multirow[t]{2}{*}{$0.545 \mathrm{~F}^{*}$} \\
\hline Vaginal delivery & 2 & (9.5) & 3 & $(7.1)$ & & & \\
\hline ati & & & & & & & \\
\hline
\end{tabular}




\begin{tabular}{|l|l|l|l|l|l|l|l|}
\hline Incomplete & 6 & $(28.6)$ & 30 & $(71.4)$ & \multirow{2}{*}{0.16} & $\begin{array}{l}0.04- \\
58.00\end{array}$ & $0.001^{*}$ \\
\hline Complete & 15 & $(71.4)$ & 12 & $(28.6)$ & & & \\
\hline
\end{tabular}

${ }^{*}$ Statistically significant at $95 \% \mathrm{Cl}$.

*F=Fischer's exact test

between the two groups. This finding indicated that women's survival was not affected by whether they were, or were not, booked for antenatal care. More cases (61.9 percent) than controls (50.0 percent) were in fact booked for antenatal care.

\section{Emergency care}

Analysis of emergency care showed that, of the 21 cases, 17 (81.0 percent) received adequate care compared to 23 (54.8 percent) in the control group. The emergency care (summoning medical assistance, quarter to half hourly monitoring of BP, temperature, respiration and pulse) was associated with the risk of maternal mortality. There was a statistically significant difference in maternal deaths between women who received and those who did not receive emergency care $(p$-value $=0.043)$. Paradoxically, the results suggest that women who were rendered emergency care for severe pre-eclampsia/eclampsia were more likely to die than those who were not given this care. However, a $95 \% \mathrm{Cl}=0.96-1.10$ (including one) suggests that the difference in chances of survival between the two groups might have occurred by chance. A greater number of cases (91.0 percent) than controls (54.8 percent) received emergency care. A possible confounding variable, namely the seriousness of patients' conditions on admission could not be accounted for from the available patients' records.

\section{The administration of anti-hypertensive/ anti-convulsant drug treatment}

The majority of both cases ( 90.5 percent) and controls (95.2 percent) were given anti-hypertensive/anticonvulsant drug treatment. The analysis revealed that there was no evidence of association between the risk of maternal death and the presence or absence of antihypertensive/anti-convulsant drug treatment ( $\mathrm{p}$-value $=0.407, \mathrm{OR}=2.11,95 \% \mathrm{Cl}=0.14-30.72$. Both cases
(90.5 percent) and controls (95.2 percent) received antihypertensive/anti-convulsant drug treatment. However, no records indicated that magnesium sulphate had been administered - neither to the cases nor to the controls.

\section{Records of fluid intake/output}

Three (14.3 percent) of the 21 cases had unrecorded fluid intakes and outputs compared to 61.9 percent of the controls. When the follow-up care was reviewed, 71.4 percent, of cases had received selected caring interventions for severe pre-eclampsia/eclampsia compared to 28.6 percent of the controls.

The risk of maternal mortality was analysed according to recorded fluid intake and output. The $p$-value $=$ 0.0004 showed that there was a significant decreased risk to women if their fluid intakes and outputs were NOT recorded. The OR of 0.10 suggests that women who had incomplete records of their fluid intake and output were less likely to die than those who had complete records of their fluid intake and output. A 95\% $\mathrm{Cl}$ of $0.02-0.45$, excluding 1 , further supported the finding that women whose fluid intakes and outputs were not recorded were less likely to die from severe pre-eclampsia/eclampsia than those whose fluid intakes and outputs were documented. Possibly better records might have been kept of dying patients in expectation of audits to be done by the maternal mortality review committee on all records of all maternal mortalities.

\section{The performance of caesarian sections}

The majority of severe pre-eclampsia/eclampsia cases (90.5 percent) and controls (92.9 percent) underwent caesarean sections in accordance with policy guidelines of MCRH. This indicates a high rate (92.1 percent) of caesarean section births among patients presenting 
with severe eclampsia/pre-eclampsia at MCRH. Type of delivery was analysed in terms of vaginal delivery or a caesarean birth. There was no significant association between the risk of maternal mortality and the type of delivery for a woman with severe pre-eclampsia/ eclampsia $(p$-value $=0.545$, OR $=0.7395 \% \mathrm{Cl}=0.05$ 9.49).

\section{Completeness of patients' records}

Fifteen (71.4 percent) of the cases had evidence of complete records of care provided compared to 28.6 percent of the controls. Documentation of care that was provided for women with severe pre-eclampsia/ eclampsia was dichotomised for analysis according to two variables of "complete" or "incomplete". The results showed that there was a statistically significant difference between women who had "complete" documentation of the care they received, with those who did not ( $p$-value $=0.001$ ) The OR of 0.16 suggests that women who had complete documentation of the care they received were more likely to die than those with incomplete records of care received. The $95 \% \mathrm{Cl}$ of 0.04-0.58 for the OR (excluding 1) further supports the statistical evidence that women who had "complete" documentation of the care they received, were more likely to die than those who had "incomplete" records.

\section{Follow-up care}

The follow-up care (one to four hourly monitoring of $\mathrm{BP}$, temperature, respiration and pulse) was associated with increased risk of maternal mortality in women with severe pre-eclampsia/eclampsia. The $p$-value of 0.001 showed that there was a statistically significant difference in death due to severe pre-eclampsia/ eclampsia between women who were given follow-up care and those who did not receive this care. The OR of 0.16 suggests that women with severe preeclampsia/eclampsia who were given follow-up care were more likely to die than those who were not provided with this care. The $95 \% \mathrm{Cl}$ of $0.04-0.16$ for the OR (excluding 1) confirms the suggestion that women who received follow-up care had less chances of surviving than those whose records showed omissions of such follow-up care.

\section{DISCUSSION OF RESEARCH RESULTS IN TERMS OF HYPOTHESES TESTED}

The two-tailed test for normal distributions was used to determine $p$-values for the differences between proportions of severe pre-eclampsia/eclampsia cases and controls. The analysis measured proportions by p-values on selected physiological and health service factors (standard of maternity care). The two-tailed test was set at $0.025 p$-value within the 0.05 significance level range.

\section{Comparison between severe pre- eclampsia/eclampsia cases and controls by diastolic blood pressure level, proportion and $\mathrm{p}$-value}

The variables for physiological factors included in the analysis were DBP and the mean DBP level $>120 \mathrm{~mm}$ $\mathrm{Hg}$ were selected for the analysis. The DBP used to define severe pre-eclampsia/eclampsia, in this study, was $>110 \mathrm{~mm} \mathrm{Hg}$.

Hypothesis 1: There is a difference in selected physiological factors associated with maternal mortality due to severe pre-eclampsia/eclampsia between nonsurviving (cases) and surviving (controls) women hospitalised at the MCRH during 1995, 1996 and 1997. (Table 3 is on the next page.)

The two-tailed test for normal distribution was used to determine the differences in factors for proportions between cases and controls. The hypothesis was rejected for the variable of DBP $\geq 110 \mathrm{~mm} \mathrm{Hg}$ and supported for a DBP above the mean DBP of $120 \mathrm{~mm} \mathrm{Hg}$. A two-tailed $p$-value of 0.039 (greater than $p$-value = 0.025 ) confirmed that there was no statistical difference in proportions between cases and controls for $\mathrm{DBP} \geq 110 \mathrm{~mm} \mathrm{Hg}$. However, when the cases and controls were compared for a mean DBP of $>120 \mathrm{~mm}$ $\mathrm{Hg}$, the results showed a statistically significant difference in proportions ( $p$-value $=0.021$ ). The findings indicated that the number of cases that had a mean DBP of $>120 \mathrm{~mm} \mathrm{Hg}$ was higher than the controls. This suggested that hypertension had progressed further in women who died.

Comparison between severe preeclampsia/eclampsia cases and controls by selected aspects of standard of maternity care factor, proportion and $p$ value 
Table 3: Comparison between severe pre-eclampsia/eclampsia cases and controls by selected diastolic blood pressure level, proportion and p-value: Mpilo Central Referral Hospital 1995-1997 ( $n=63$ )

\begin{tabular}{|l|l|l|l|}
\hline DBP & $\begin{array}{l}\text { Proportion of } \\
\text { cases with } \\
\text { characteristic }\end{array}$ & $\begin{array}{l}\text { Proportion of } \\
\text { controls with } \\
\text { characteristic }\end{array}$ & $\begin{array}{l}\text { Difference between } \\
\text { proportions }\end{array}$ \\
\hline & $\mathbf{n = 2 1}$ & $\mathbf{n}=\mathbf{4 2}$ & $\begin{array}{l}\text { Normal distribution } \\
\text { p-values }\end{array}$ \\
\hline $\begin{array}{l}\text { Highest DBP } \geq 110 \\
\mathrm{~mm} \mathrm{Hg}\end{array}$ & 81.0 & Percent & 0.039 \\
\hline $\begin{array}{l}\text { DBP level above } \\
\text { mean }(120 \mathrm{~mm} \mathrm{Hg})\end{array}$ & 76.1 & 97.6 & $0.021^{*}$ \\
\hline
\end{tabular}

* Statistically significant at 0.025 p-value

The standard of maternity care factors were analysed using the two-tailed test for normal distribution for differences in proportions between cases and controls for health care factors.

Hypothesis 2: There is a difference in selected aspects of standard of maternity care received by nonsurviving (cases) and surviving (controls) women hospitalised for severe pre-eclampsia/eclampsia at MCRH during 1995, 1996 and 1997 respectively.

Using the two-tailed test for the normal distribution for differences in proportions, the hypothesis was rejected for emergency care ( $p$-value $=0.035)$ and anti-hypertensive/anti-convulsant drug treatment $(p$-value $=$ 0.469 ). The $p$-values of $>0.025$ confirm that there were no differences in proportions with respect to the aspects of care. However, in terms of clinical implications, the levels of cases who were provided with care were proportionally higher compared to that of the controls suggesting that the cases received better obstetric/maternity care for their condition, or that care rendered to cases was more accurately recorded than for the controls.

The hypothesis was supported for fluid intake and output recording, $(p$-value $=0.001)$ follow-up care $(p$-value $=0.001)$ and documentation of care $(p$-value $=0.001)$ variables. The two-tailed $p$-value $>0.025$, provides further evidence of the differences in proportions of the normal distribution test between cases and controls. The differences imply that a higher proportion of severe pre-eclampsia/eclampsia cases than controls were provided with these aspects of standard maternity care, or that such care was more accurately recorded for cases than for controls.

When the standard of maternity care was analysed regarding variables including emergency care, fluid intake and output recording, follow-up care and documentation of care given, it appeared as if women who died received better care than those who survived in relation to these aspects of care. When this risk was further investigated unexpected findings were revealed. Women with a DBP $\geq 110 \mathrm{~mm} \mathrm{Hg}$ and a mean DPB $>120 \mathrm{~mm} \mathrm{Hg}$, and with omission of emergency care, fluid intake and output recordings, follow-up care and documentation of care were less likely to die from severe pre-eclampsia/eclampsia. The variables of fluid intake and output recording, follow-up care and documentation of care remained significant after a stepwise regression test.

Evidence from this research revealed that preeclampsia/eclampsia was more common among primgravidae, confirming that the first pregnancy is a 
Table 4: Comparison between severe pre-eclampsia/eclampsia cases and controls by selected aspects of standard of maternity care factor, proportion and p-value: Mpilo Central Referral Hospital 1995-1997 $(n=63)$

\begin{tabular}{|l|l|l|l|}
\hline $\begin{array}{l}\text { Standard of maternity } \\
\text { care factor }\end{array}$ & $\begin{array}{l}\text { Proportion of } \\
\text { cases provided } \\
\text { with care }\end{array}$ & $\begin{array}{l}\text { Proportion of } \\
\text { controls } \\
\text { provided with } \\
\text { care }\end{array}$ & $\begin{array}{l}\text { Difference } \\
\text { between } \\
\text { proportions }\end{array}$ \\
\hline & $\mathbf{n = 2 1}$ & $\mathbf{n = 4 2}$ & \\
\hline Emergency care given & Percent & Percent & \\
\hline $\begin{array}{l}\text { Anti-hypertensive/anti-convulsant } \\
\text { drug treatment }\end{array}$ & 91.0 & 54.8 & 0.035 \\
\hline Fluid intake and output recording & 80.5 & 95.2 & 0.469 \\
\hline Follow-up care given & 71.4 & 38.1 & $0.001^{*}$ \\
\hline $\begin{array}{l}\text { Documentation of care (complete } \\
\text { records) }\end{array}$ & 71.4 & 28.6 & $0.001^{*}$ \\
\hline
\end{tabular}

${ }^{*}$ Statistically significant at 0.025 p-value

Table 5: Significant factors associated with severe pre-eclampsia/eclampsia and risk of maternal death for cases and controls: Mpilo Central Referral Hospital 1995-1997. Adjusted OR and p-value $(n=63)$

\begin{tabular}{|l|l|l|}
\hline Factor & Adjusted OR & P-value \\
\hline Emergency care & 1.21 & 0.125 \\
\hline Fluid intake and output recording & 1.53 & $0.000^{\star}$ \\
\hline Follow-up care & 1.41 & $0.004^{\star}$ \\
\hline Documentation of care & 2.10 & $0.001^{\star}$ \\
\hline
\end{tabular}

*Statistically significant at $95 \% \mathrm{Cl}$

risk factor for developing severe pre-eclampsia/ eclampsia, emphasising the need for close surveillance of this group of women. Anaemia was common among both cases and controls, with a higher proportion of anaemic cases than controls. Pregnancy aggravates anaemia and many other diseases. Antenatal care plays a vital role in improving maternal health by early detection of complications and by providing opportunities to identify and treat illnesses that might otherwise go unnoticed until it is too late to implement effective interventions (WHO, 1993:5).
In Zimbabwe, the majority of care-providers are nurses and midwives who can make major contributions towards reducing MMRs. They control how and what health information is communicated to women. They also decide what care should be provided to women who present with obstetric complications such as those related to severe pre-eclampsia/eclampsia.

The reason why women died, despite having been offered better recorded care than the survivors might be embodied in a number of determinant factors. Firstly, 
each woman brings with her into the health care system personal factors influencing her responses to the care provided. Factors such as pre-existing debilitating undiagnosed diseases, such as HIV/AIDS (for which pregnant women are not routinely tested in Zimbabwe) and malaria (Bulawayo lies within a known geographical malaria area, but pregnant women were also not routinely tested for malaria), might have influenced women's chances of responding favourably to treatment or maternity care. Furthermore, although women who died reportedly received better documented care, physiologically women's responses to treatment might have been influenced by their resilience to complications of severe pre-eclampsia/eclampsia, influenced by their general state of health/illness. The controls were presumably not under threat, in terms of their physiological responses while those who died might have encountered further progression of their conditions. This could be neither confirmed nor denied from studying these patients' obstetric records. However these results appeared to be contrary to expectations. The reason for this could be that midwives normally make sure that records of dying patients are complete in view of the anticipated maternal mortality review committee investigations. Unfortunately, the assumption exists worldwide that midwifery/nursing records are not always true reflections of the care that was rendered to patients. A study in the USA demonstrated that nursing records did, in fact, not show a complete picture of the interventions provided or their effects (Hale, Thomas, Bond \& Todd, 1997:213). Whether or not this was the case in Zimbabwe could neither be confirmed nor denied from the available data.

\section{LIMITATIONS OF THE RESEARCH}

The major limitation was that data were collected from one hospital because of limited time available and nonforthcoming permission from another health care institution with similar functions. The results, therefore, cannot be generalised. Another limitation was imposed by merely studying the records of cases and controls. More information could have been obtained by observing the care recorded and comparing these records with the actual care rendered.

\section{CONCLUSION}

Variables such as diastolic blood pressure (DBP), fluid intake and output recording, follow-up care (hourly to four hourly observation of blood pressure, temperature, respiration and pulse) and documentation of care, appeared to produce research results which could be regarded as being contradictory to expectations. These variables remained significant after the stepwise logistic regression. The reason for this could be that midwives ensure that records of dying patients are complete in expectation of the Maternal Mortality Review Committee's anticipated investigations.

While acknowledging that the causes of MMRs can be complex, the contribution of severe pre-eclampsia/ eclampsia to maternal mortality remains unacceptably high in Zimbabwe. The critical issue remains that maternal mortality due to severe pre-eclampsia/ eclampsia can either be prevented or reduced. The possibility of reduction is real if nurse-midwives respond to the women's needs timeously and provide good quality care during pregnancy and childbirth. As the WHO (1999:36) states "... good-quality care implies care that is client-oriented and sensitive to the needs of communities and individuals, that maintains high technical quality through adoption of sound norms and standards, and that avoids the use of inappropriate technologies and over 'medicalisation'."

The nurses' and midwives' potential in reducing maternal mortality can be realised through the process of health assessment to identify risk factors in every woman; by providing women with relevant information to promote self-care and ownership of health; through prompt appropriate treatment of detected disorders such as anaemia and malaria; through timely referral of women with detected high-risk pregnancy conditions for specialised care; and through appropriate use of the partogram to assist in detecting abnormal labour.

\section{RECOMMENDATIONS}

The retrospective obstetric records audit played a central role in providing insight into factors associated with maternal mortality, which is expected to strengthen strategies to reduce maternal mortalities from severe pre-eclampsia/eclampsia in Zimbabwe through regular auditing of care and surveillance. The results of such audits should be discussed at in-service education sessions. 
As magnesium sulphate has been shown to reduce the severity of pre-eclampsia/eclampsia and as it was not administered to a single patient, Zimbabwe should urgently revise its policy guidelines to include the safe administration of magnesium sulphate to these patients. Nurses and midwives need to receive the required in-service education to do so safely and effectively. Midwives should be allowed to keep stocks of magnesium sulphate and to administer it to women with impending signs of pre-eclampsia/eclampsia prior to transferring them from clinics to hospitals.

Essential midwifery drugs, including oxytocics, antibiotics, antihypertensives and anti-convulsants (in addition to magnesium sulphate) should be available at all centres rendering midwifery services. Treatment protocols should clearly specify under which circumstances what dosages of these drugs could be administered and these protocols should be discussed during in-service education sessions.

Although the partograph is used to monitor the progress of labour throughout Zimbabwe, its action guidelines need to be researched and adapted to the unique situations in Zimbabwe. For example, critical points of unsatisfactory progress when the patient must be referred to more advanced levels of health care should be specified taking into account the number of hours the patient is likely to be in transit prior to reaching the secondary or tertiary health care facility. Although the research findings of this retrospective case control study could not substantiate the premise that late arrivals, during advanced stages of complications due to pre-eclampsia/eclampsia, adversely affected the women's chances of survival, this possibility needs to be addressed and accommodated in future policies.

All pregnant women with hyperpyrexia should be tested, and if necessary treated, for malaria in the Bulawayo area, and indeed in all areas where malaria is endemic in Africa.

Treatment of obstetric conditions could be enhanced if the women's HIV status could be known. Future antenatal care policies should investigate possibilities of offering these tests to pregnant women in Zimbabwe.

\section{CONCLUSIVE REMARKS}

Women need not die from high-risk pregnancy conditions such as severe pre-eclampsia/eclampsia if health care providers work consistently towards reducing maternal mortalities, audit each case and strive to prevent similar occurrences in future. "For obstetricians and midwives practising in developing countries, maternal mortality is not about statistics. It is about women, women who have names, women who have faces. Faces, which we have seen in the throes of agony, distress and despair. Faces which continue to live in our memories and continue to haunt our dreams. Not simply because these are women in the prime of their lives who die at a time of expectation and joy; not simply because a maternal death is one of the most terrible ways to die ... but above all, because almost every maternal death is an event that could have been avoided, and should never have been allowed to happen" (Starrs, 1997:7).

\section{LIST OF REFERENCES}

ABOUZAHR, C \& ROYSTON, C 1991: Maternal mortality: a global factbook. Geneva: WHO.

ABRAMSON, JH 1990: Survey methods in community medicine: an introduction to epidemiology and evaluative studies; $3^{\text {rd }}$ edition. London: Churchill Livingstone.

ASHWORTH, MF 1990: Harare Hospital maternal mortality for 1987 and a comparison with previous reports. Central African Journal of Medicine, 36:209-211.

BENNETT, RV \& BROWN, LK 1999: Myles‘ textbook for midwives; $13^{\text {th }}$ edition. London: Churchill Livingstone.

BOES, EM 1987: Maternal mortality in Southern Africa, 1980-1982. Part I: Pregnancy can be lethal. South African Medical Journal, 71:158-161.

CAVANAGH, D; WOODS, RE \& O'CONNOR, TCF 1978: Obstetric emergencies; 2nd edition. New York: Harper \& Row.

CRAFT, H 1999: Problems of pregnancy (In: Bennett, RV \& Brown, LK 1999: Myles' textbook for midwives; $13^{\text {th }}$ edition . London: Churchill Livingstone.)

DEPARTMENT OF HEALTH 1994: Report of the confidential enquiries into maternal deaths in the United Kingdom 1988-1990. London: Her Majesty's Services Office.

DONABEDIAN, A 1986: Evaluating the quality of medical care. Millband Memorial Quarterly, 63(3):206-209.

DOWNE, S 1991: The price of motherhood. Nursing Times, 87:3335.

DULEY, L \& HENDERSON-SMART, D 2000a: Magnesium sulphate versus diazepam for eclampsia. Cochrane Review: Cochrane 
Library, Issue 1, 2000. Oxford: Update Software.

DULEY, L \& HENDERSON-SMART, D 2000b: Drugs for rapid treatment of very high blood pressure during pregnancy. Cochrane

Review: Cochrane Library, Issue 1, 2000. Oxford: Update Software.

DULEY, L; GULMEZOGLU, AM \& HENDERSON-SMART, D 2000: Anticonvulsants for women with pre-eclampsia. Cochrane Review: Cochrane Library, Issue 1, 2000. Oxford: Update Software. HALE, CA; THOMAS, LH; BOND, S \& TODD, C 1997: The nursing record as a research tool to identify nursing interventions. Journal of Clinical Nursing, 6:207-214.

HOWSON, PH; HARRISON, PF; HOTRA, D \& LAW, M 1996: In her lifetime: female mortality and morbidity in sub-Saharan Africa. Institute of Medicine. Washington DC: National Academy Press. JACOBSEN, BS 1997: Univariate descriptive statistics (In: Munro, BH 1997: Statistical methods for health care; $3^{\text {rd }}$ edition. New York: JB Lippincott.)

KAHN, HA \& SEMPOS, CT 1989: Statistical methods in epidemiology. New York: Oxford University Press.

KAPLAN, PW \& REPKE, JT 1994: Eclampsia. Neurologic Clinics, 12(3):565-582.

KHAN, AR; JAHAN, FA \& BEGUM, SF 1986: Maternal mortality in rural Bangladesh: The Jamalpur District. Studies in Family Planning, 17(1):7-12.

LINDBERG, JB; HUNTER, ML \& KRUSZEWSKI, AN 1994: Introduction to nursing concepts, issues and opportunities; 2nd edition. Philadelphia: JB Lippincott.

LLOYD, C \& LEWIS, VM 1999: Hypertensive disorders of pregnancy (In: Bennett, RV \& Brown, LK 1999: Myles' textbook for midwives; 13th edition. London: Churchill Livingstone.)

MCRH see Mpilo Central Referral Hospital

MINISTRY OF HEALTH 1981: Planning for equity in health: a sectoral review and policy statement. Harare: Zimbabwe Ministry of Health \& Child Welfare.

$\mathrm{MOH}$ see Ministry of Health

MOODLEY, J 1998: Saving mothers: report on confidential enquiries into maternal deaths in South Africa. Pretoria: Department of Health. MPILO CENTRAL REFERRAL HOSPITAL 1996: Annual report. Bulawayo: Mpilo Central Referral Hospital.

MPILO CENTRAL REFERRAL HOSPITAL 1997: Obstetric/ Gynaecological Records 1994-1997. Bulawayo: Maternity Units. Bulawayo: Mpilo Central Referral Hospital.

MPILO CENTRAL REFERRAL HOSPITAL 1997: Health Information Unit Obstetric/Gynaecological Records 1994-1997. Bulawayo: Mpilo Central Referral Hospital.

MUNRO, BH 1997: Statistical methods for health care research. New York: JB Lippincott.

NAAOG see Nurses' Association of American College of Obstetricians \& Gynaecologists.
NURSES' ASSOCIATION OF AMERICAN COLLEGE OF OBSTETRICIANS \& GYNAECOLOGISTS 1990: Obstetricians and gynaecologists nursing practice resource: quality assurance. Washington, DC: Organisation for Obstetric and Gynaecologic \& Neonatal Nurses.

PAUL, KB 1993: Maternal mortality in Africa: 1980-1987. Social Science \& Medicine, 37(6):745-752.

POLIT, DF \& HUNGLER, BP 1995: Nursing research: principles and research; $5^{\text {th }}$ edition. New York: JB Lippincott.

POOLE, JH 1995: Hypertension, haemorrhage and maternal infections (In: Bobak, IM, Lowdermilk, DL, \& Jensen, SEP 1995: Maternal nursing; $4^{\text {th }}$ edition. Boston: CV Mosby.)

ROYSTON, E \& ARMSTRONG, S 1989: Preventing maternal mortality. Geneva: WHO.

SCHAUF, CL; MOFFETT, DF \& MOFFETT, SB 1990: Human physiology. Foundations and frontiers. Toronto: Times Mirror.

SIBAI, BM; RAMADAN, MK; USTA, I; SALAM, M; MERCER, BM \& FRIEDMAN, SA 1993: Maternal morbidity and mortality in 442 pregnancies with haemolysis, elevated liver enzymes, and low platelets (HELLP Syndrome). American Journal of Obstetrics \& Gynaecology, 169:1049-1054.

STARRS, A 1997: The safe motherhood action agenda: priorities for the next decade. a report on the safe motherhood technical consultation, 18-23 October 1997, Colombo, Sri Lanka. New York: Family Health International.

SURRATT, N 1993: Severe pre-eclampsia: implications for critical care obstetric nursing. Journal of Obstetric Gynaecologic \& Neonatal Nursing, 22(6):500-507.

TALBOT, LA 1995: Principles and practice of nursing research. St Louis: CV Mosby.

WALLENBURG, HCS 1989: Detecting hypertensive disorders of pregnancy (In: Chalmers, I; Enkin, M \& Keirse, MJNC 1989: Effective care in pregnancy and childbirth Volume 1. Parts i-v. Oxford: Oxford University Press.)

WHO see World Health Organisation.

WORLD HEALTH ORGANISATION 1993: How antenatal care can improve maternal health. Safe Motherhood Newsletter Worldwide Activity, 11, March-June:4-5.

WORLD HEALTH ORGANISATION 1995: Magnesium sulphate is the drug of choice for eclampsia: Safe Motherhood Newsletter of the World Activity, 18:2-20.

WORLD HEALTH ORGANISATION 1996: Eclampsia module: midwifery FRH/MSM/96.5. Geneva: WHO.

WORLD HEALTH ORGANISATION 1999: Reduction of maternal mortality: a joint WHO/UNFPA/UNICEF/World Bank Statement. Geneva: WHO. 


\title{
ILLNESS COGNITIONS, DOCTOR-PATIENT COMMUNICATION AND PRESCRIPTION ADHERENCE AMONG FIRST DIAGNOSED HYPERTENSIVE PATIENTS FROM A RURAL TEACHING HOSPITAL IN SOUTH AFRICA
}

\author{
K Peltzer \\ Health Behaviour Research Unit, University of the North \\ Corresponding author: peltzerk@mweb.co.za
}

\section{LB Khoza}

Associate Professor, Department of Nursing, University of Venda for Science and Technology

\section{ME Lekhuleni}

Lecturer, Department of Nursing, University of the North

\section{Alberts}

Associate Professor, Department of Medical Sciences, University of the North

\author{
J Mekwa \\ Professor, Department of Nursing, University of Cape Town
}

\section{E Sethosa}

Research mentor, Population Council, Johannesburg

Keywords: black South Africans; doctor-patient communication; hypertensives; illness cognitions; medication adherence

\begin{abstract}
This study examines the relationship between illness cognitions, doctor-patient communication and the use of prescribed medication among patients first diagnosed with hypertension in the outpatient department of a rural South African teaching hospital. The sample included two men and 43 women, in the age range of 38 to 85 years, $(M=60.5$ years, $S D=11.5$ years); 14 (31\%) were 65 years and above. Outcome measures included doctorpatient communication, recall interview, illness cognitions, and anthropometrical measurements. From the 45 patients studied 23 (51\%) were not adherent with prescription medication. Major findings were that doctor-patient communication, most illness cognitions, and healthy behaviour of the patient were not associated with adherence behaviour. Perceived stress and the belief of incurability of hypertension were, however, related with adherence behaviour. Patients frequently mentioned mental and environmental stress as causative and management beliefs. On the contrary, the treating physicians did not allude to mental and environmental stress. Physicians gave little lifestyle health education. In instances where it was given, most patients seemed to practice it.
\end{abstract}

\section{OPSOMMING}

Hierdie studie ondersoek die verwantskap tussen siekte-kognisies, dokter-pasiënt kommunikasie en die gebruik van voorskrifmedisyne onder pasiënte wat die eerste keer met hipertensie gediagnoseer is, in die buitepasiëntafdeling van ' $n$ landelike Suid-Afrikaanse opleidingshospitaal. Die steekproef het twee mans en 43 vroue, binne die ouderdomsgroep 38-85 jaar inges/uit ( $M=60.5$ jaar, $S=11.5$ jaar); 14 (31\%) was 65 jaar en ouer. Uitkomsmetings het dokter-pasiënt-kommunikasie, herbesoek-onderhoude, siekte-kognisies, en antropometriese metings inges/uit. Van die 45 pasiënte wat bestudeer is, het 23 nie gehoor gegee aan hul voorskrifmedikasie nie. Die belangrikste 